\title{
PORNOGRAFI DAN PORNOAKSI: PERSPEKTIF AGAMA DAN KESEHATAN MENTAL
}

\author{
Syamsu Syauqani*
}

\section{Abstract}

Discussing about pornography and erotic actions is mostly about the debate among religious defenders, cultural practitioners and activists of buman rights. This is due to the fact that the three parties have their own point of views in perceiving the constitution of pornography and erotic actions. They have different perception especially from religion's point of view. This writing - with no intention to interfere the debate-tries to understand pornography and erotic actions from religion and mental health.

Religion in this context is not meant as the complicated or liberal term but rather on the normative-theological doctrine which intents to give both physical and mental healthy life. Islam claims to have a teaching which leads to mental health by forbidding immoral deeds such as pornography and erotic actions. Therefore, to support the religion perception on pornography and erotic actions, this writing reveals that pornography and erotic actions as 'mental sickness'.

Keywords: Aurat, Exhibisionisme, Foyeurisme, Kebebasan, Keamanan Sosial, Pendidikan Seks.

BELAKANGAN ini masalah pornografi dan pornoaksi begitu hangat diperbincangkan di masyarakat. Pemicunya adalah dilontarkannya Randangan Undang-Undang Anti Pornografi dan Pornoaksi (RUU APP) oleh DPR ke masyarakat. Hampir semua lapisan masyarakat turut memberikan sumbangan pemikirannya tentang permasalahan tersebut. Mulai kaum agamawan yang

*Penulis adalah dosen pada Fakultas Syari'ah IAIN Mataram, Jln. Pendidikan 35 Mataram. email: fath_smart@yahoo.com 
"merasa sangat berkepentingan" dan mempunyai tanggung jawab moral paling besar dalam permasalahan itu, bahkan merupakan panggilan agama. Kemudian juga para budayawan, kaum intelektual kampus, dan juga para aktifis, baik yang "mengklaim berbasis agama" maupun yang mengklaim "memperjuangkan demokasi dan HAM," khususnya hak-hak kaum perempuan. Mereka ini juga merasa memiliki tanggungjawab moral untuk memperjuangkan hak-hak perempuan, yang menurut mereka sebagai pihak yang selalu "dijadikan korban" dalam setiap tindakan pornografi dan pornoaksi.

Meski berbagai kelompok di atas saling bertentangan, tetapi kesemuannya sepakat untuk menolak adanya pornografi dan pornoaksi dalam bentuk apapun. Karena itu perdebatan dan pertentangan yang muncul lebih pada persoalan perlu tidaknya ketidaksetujuan terhadap pornografi dan pornoaksi itu diatur dalam perundangan-undangan yang khusus. Titik temu itulah yang semstinya dikembangkan, sehingga pertentangan yang terjadi tidak semakin tajam. Tulisan ini berupaya mengelaborasi berbagai argumen, khususnya sudut pandang agama dan kesehatan mental, yang memberi penegasan mengapa pornografi dan pornoaksi dalam bentuk apapun harus ditolak.

\section{Tinjauan Historis Pornografi dan Pornoaksi}

Dalam merumuskan pengertian pornografi dan pornoaksi, perlu dikemukakan asal kata pornografi dan historis pornoaksi dalam tataran perilaku terlebih dahulu. Kata pornografi berasal dari bahasa Yunani, porne artinya pelacur, dan graphein artinya ungkapan. ${ }^{1}$ Di Yunani pada abad keempat sebelum masehi,

${ }^{1}$ Dalam Kamus Besar Bahasa Indonesia disebutkan yang disebut pornograpi adalah penggabaran tingkah laku secara erotis dengan lukisan atau tulisan untuk membangkitkan nafsu birahi. Lihat, Purwadarminta, Kamus Besar Bahasa Indonesia (Jakarta: Balai Pustaka, 1989), 696. 
terdapat seorang Yunani yang cantik jelita bernama Phryne dari Thespia. Ia seorang Hetaerai, yaitu seorang perempuan yang kehidupannya hanya untuk bersenang-senang dengan laki-laki. Hetaerai berbeda dengan porne, yaitu perempuan pelacur yang digunakan dan dibayar setiap hari, berbeda pula dengan istri yang berfungsi sebagai pemelihara rumah tangga dan keturunan yang dapat dipercaya. Phyrne pernah dituduh sebagai perempuan yang mengkorupsi para jejaka Athena. Ketika pengadilan akan menjatuhkan hukuman terhadap Phyrne, pembela Phryne bernama Hyperides mengajukan pembelaan dengan cara meminta Phyrne berdiri di suatu tempat di depan sidang dengan posisi yang dapat dilihat oleh semua yang hadir. Phyrne menanggalkan pakaiannya satu per satu, sehingga seluruh keindahan tubuhnya tampak oleh hakim dan seluruh yang hadir. Dan akhirnya, Phyrne dibebaskan dari hukuman. Pertunjukan Phyrne itulah awal dari pertunjukan striptease. ${ }^{2}$ Sehingga, definisi yang tepat atas pornografi dan pornoaksi dibatasi aspek eksploitasi dan perilaku seksual atas dasar kesengajaan yang dalam konteks Hak Asasi Manusia (HAM), tinjauan norma ketimuran ${ }^{3}$ dan agama.

Dalam perjalanan masa ke masa, naluri terendah manusia, yaitu pemenuhan naluri seksual tersebut banyak menggunakan kemajuan teknologi, dapat berupa hasil gambar dua dimensi atau dapat berupa gambar bergerak atau film. Hasil teknologi tersebut dapat berupa: VCD bajakan, situs-situs porno di internet, media massa, media elektronik, buku-buku berbau porno, diskotik, dan tempat hiburan. Sehingga, gambar tersebut juga

${ }^{2}$ Neng Djubaedah, Pornografi dan Pornoaksi Ditinju dari Segi Hukum Islam (Jakarta: Kencana, 2003), 138.

${ }^{3}$ Kata "ketimuran" yang dimaksud adalah manusia sebagai individu yang dimana bangsanya memiliki norma, etika, adat istiadat, kebiasaan, akhlak, watak, sikap dan cara berpikir yang sangat kaku, ini karena dipengaruhi oleh perjalanan sejarah kebudayaan bangsa dan nilai-nilai agama yang banyak mempengaruhinya. 
mampu membangkitkan naluri terendah manusia, dan pada akhirnya akan melahirkan perilaku pornografi dan pornoaksi.

\section{Agama dan Keharusan Menutup Aurat}

Aurat merupakan bagian dari akar pro dan kontra terhadap diskursus Pornografi dan Pornoaksi. Dalam ajaran Islam ada batasan-batasan yang digariskan dalam permasalahan aurat, baik pada laki-laki maupun pada perempuan. Secara etimologis kata 'Awrah adalah masdar dari 'âra-ya'uru-awran wa awratan; jamaknya 'awrâh. Aurat memiliki beberapa arti: aib, cacat atau cela; celahcelah suatu tempat; semua hal yang dirasa malu. ${ }^{4}$ Al-Râzî mengatakan, aurat adalah segala perkara yang dirasa malu jika tampak.

Dalam teks al Qur'an menyatakan kata 'awrah dua kali dalam satu ayat Qs. al-Ahzâb (33):13, inna buyûtana 'awrah wa mâ hiya bi 'awrah. Maknanya sesuai dengan makna bahasanya, yaitu tempat atau celah yang terbuka atau tak terlindungi dan dikhawatirkan. ${ }^{5}$

Mengenai batasan aurat laki-laki para ulama berpendapat sebagian besar hanya dubur dan kemaluan, sedangkan paha tidak termasuk aurat. ${ }^{6}$ Muhammad bin Jahsyî menuturkan: aku pernah bersama Rasul melewati Ma'mar, sedangkan kedua pahanya terbuka lalu Rasul bersabda : wahai Ma'mar, tutupi kedua pahamu, sesunggubnya kedua paha itu auraț. Jarhad al-Aslâmî menuturkan, ia sedang dimasjid, lalu Nabi saw. datang dan memandangnya, sementara pahanya terbuka, lalu Nabi bersabda: "Sesungguhnya

${ }^{4}$ Wahbah al-Zuhaylî, al-Fiqh al-Islâmî wa-Adillatuh, Jilid I (Damaskus: Dâr al-Fikr, 1997), 738. Lihat juga, Karam al-Bastani, al-Munjid Fi al-Lughah wa-al'Alam (Beirut: Dâr al-Masyriq, 1987), 537.

5 Al-Qur'an dan Terjemahannya (Madinah: Mujamma' al-Malik Fahd li Thibâ'ah al-Mushah al-Syariff 1418 H) 668.

'Sayyid Sabiq, Fiqh al-Sunnah, Jilid I (Kairo: Dâr al-Fath lil 'Ilam Arabî, 1996), 138.

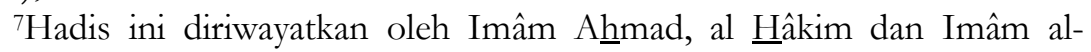
Bukhârî dalam Kitâb Tarikhnya, lihat: Ibid., 140. 
paha termasuk aurat". 8 Aisyah juga menuturkan: Rasul sedang duduk dan tersingkap pahanya. Lalu Abu Bakar meminta izin dan Beliau tetap dalam keadaan itu. Kemudian Umar meminta izin dan beliau juga tetap dalam keadaan itu, kemudian Usman meminta izin, lalu Rasul mengulurkan pakaiannya, ketika mereka berdiri. Aku (Aisyah) bertanya,"Wahai Rasulullah, Abu Bakar dan Umar meminta izin dan engkau izinkan, sedangkan engkau dalam keadaan itu. Ketika Usman meminta izin engkau ulurkan pakaianmu." Rasul menjawab, "Wahai Aisyah, apakah aku tidak merasa malu dari seorang laki-laki yang demi Allah, malaikat pun merasa malu padanya?"9

Menurut ketentuan ushul, jika terdapat pertentangan antara perkataan dan perintah Rasul dengan perbuatannya maka perbuatannya itu harus dibawa sebagai kekhususan baginya, sedangkan perkataan dan perintahnya berlaku untuk kaum muslim secara umum. Jadi, paha bukan aurat sedangkan bagi kaum muslim paha sebagai aurat. Dengan demikian, semua hadis di atas bisa digunakan sebagai dalil tanpa mengabaikan satu hadis pun yang sah dijadikan dalil. Walhasil, aurat laki-laki adalah anggota tubuh antara pusar sampai ke lutut, di mana pusar dan lutut tidak termasuk aurat.

Sedangkan aurat perempuan, menurut mayoritas ulama fiqh adalah seluruh badan wanita kecuali wajah dan telapak tangan. ${ }^{10}$ Allah swt. berfirman: "Katakanlah kepada para wanita

${ }^{8}$ Hadis ini diriwayatkan oleh Imâm Mâlik, Imâm Ahmad, Imâm Abû Daud, dan Imâm Tirmîdzî menghukumnya Hasan. Oleh Sayyid Sabiq kedua hadis ini dimasukkan kedalam bujjah milik kelompok ulama fiqh yang memandang bahwasanya paha, lutut, dan bagian atas kemaluan sampai pusar adalah aurat laki-laki. Ibid., 138-40.

${ }^{9}$ Hadis Anas ra. dan Sayyidah 'Aisyah ini diriwayatkan oleh Imâm Ahmad dan Imâm Bukhârî, menurut Sayyid Sabiq, kedua hadis ini menjadi argumen bagi kelompok yang berpendapat bahwasanya paha, lutut dan bagian atas kemaluan sampai pusar tidak termasuk aurat laki-laki. Ibid., 1389 .

${ }^{10}$ Wahbah, al-Fiqh..., 744. 
mukmin,"hendaklah mereka menahan pandangannya, memelihara kemaluannya dan janganlah mereka menampakkan perbiasannya, kecuali yang biasa tampak padanya". Pada ayat ini dinyatakan seluruh tubuh wanita adalah aurat, kecuali yang biasa tampak. Riwayat yang sahih menyatakan bahwa Ibn Abbas, Ibn Umar dan 'Aisyah, menafsirkan kalimat illa ma zhbahara minha (kecuali yang biasa tampak darinya) dengan wajah dan kedua telapak tangan sampai pergelangan tangan. ${ }^{11}$

Dengan mengetahui batasan aurat yang jelas, maka setiap bagian dari pelaku sosial dalam masyarakat dapat membedakan antara yang hak untuk dilihat atau diperlihatkan ke dan oleh orang lain atau tidak. Sehingga, norma yang berjalan dalam ranah kemasyarakatan tidak terjadi kekaburan antara norma, hak asasi dan nilai agama. Dalam tataran praktis kehidupan, khususnya dalam kehidupan keluarga, ajaran agama tentang aurat diwujudkan dalam bentuk "pendidikan seks" yang mencakup ajaran-ajaran: ${ }^{12}$

1. Menanamkan rasa malu pada anak.

Rasa malu harus ditanam kepada anak sejak dini. Jangan biasakan anak-anak, walau masih kecil, bertelanjang di depan orang lain; misalnya ketika keluar kamar mandi, berganti pakaian dan sebagainya. Membiasakan anak perempuan sejak kecil berbusana muslimah menutup aurat juga penting untuk menanamkan rasa malu sekaligus mengajari anak tentang auratnya. ${ }^{13}$

2. Menanamkan jiwa maskulinitas pada anak laki-laki dan jiwa feminitas pada anak perempuan.

Secara fisik maupun psikis, laki-laki dan perempuan mempunyai perbedaan mendasar. Perbedaan tersebut telah diciptakan sedemikian rupa oleh Allah. Adanya perbedaan ini

${ }^{11}$ Sabiq, Fiqh..., 140.

${ }^{12} Z$ ulia Ilmawati, "Pendidikn Seks Untuk Anak", Al-Wa'ie, 30 April 2006, 25

${ }^{13}$ Ibid. 
bukan untuk saling merendahkan, namun semata-mata karena fungsi yang berbeda yang kelak akan diperankannya. Mengingat perbedaan tersebut, Islam telah memberikan tuntutan agar masing-masing fitrah yang telah ada tetap terjaga. Islam menghendaki agar laki-laki memiliki kepribadian maskulin dan perempuan memiliki kepribadian feminin. Islam tidak menghendaki wanita menyerupai lakilaki, begitu juga sebaliknya. Untuk itu, harus dibiasakan dari kecil anak-anak berpakaian sesuai dengan jenis kelaminnya, mereka juga harus diperlakukan sesuai dengan jenis kelaminnya. Ibnu Abbas ra. berkata: Rasulullah saw. "Allah melaknat laki-laki yang berlagak wanita dan wanita yang berlagak meniru laki-laki". 14

3. Memisahkan tempat tidur mereka.

Usia antara 7-10 tahun merupakan usia saat anak mengalami perkembangan yang pesat. Anak mulai melakukan eksplorasi ke dunia luar. Anak tidak hanya berpikir sesuatu yang ada di luar dirinya. Pemisahan tempat tidur merupakan upaya untuk menanamkan tentang eksistensi dirinya. Jika pemisahan tempat tidur terjadi antara anak telah dilatih untuk berani mandiri. Anak juga dicoba untuk belajar melepaskan perilaku lekatnya (attachment behavior) dengan orang tuanya. Jika pemisahan tempat tidur dilakukan terhadap anak dengan saudaranya yang berbeda jenis kelamin, secara langsung ia telah ditumbuhkan kesadarannya tentang eksistensi perbedaan jenis kelamin. ${ }^{15}$

4. Mengenalkan waktu berkunjung.

Tiga ketentuan waktu yang tidak diperbolehkan anak-anak memasuki ruangan (kamar) orang dewasa kecuali meminta izin terlebih dahulu adalah: sebelum shalat subuh, tengah hari dan setelah shalat isya'. Aturan ini ditetapkan mengingat di

${ }^{14}$ Ibid.

${ }^{15}$ Ibid., 26 
antara ketiga waktu tersebut merupakan waktu aurat, yakni waktu ketika badan atau aurat orang dewasa banyak terbuka. ${ }^{16}$ Jika pendidikan norma semacam ini ditanamkan pada anak maka ia akan menjadi anak yang memiliki rasa sopan-santun dan etika yang luhur. ${ }^{17}$

5. Mendidik menjaga kebersihan alat kelamin.

Mengajari anak untuk menjaga kebersihan alat kelamin selain agar bersih dan sehat, juga agar ia paham tentang najis. Anak juga harus dibiasakan untuk buang air pada tempatnya (toilet training). Dengan cara ini akan terbentuk pada diri anak sikap hati-hati, mandiri, mencintai kebersihan, mampu menguasai diri, disiplin, dan sikap moral yang memperhatikan tentang sopan santun dalam melakukan hajat. ${ }^{18}$

6. Mengenalkan mahromnya.

Tidak semua orang berhak dinikahi oleh seorang laki-laki. Siapa saja perempuan yang diharamkan dan yang dihalalkan telah ditentukan oleh syari'at Islam. Ketentuan ini harus diberikan pada anak agar ditaati. Dengan memahami kedudukan perempuan yang menjadi mahram, diupayakan agar anak mampu menjaga pergaulan sehari-harinya selain dengan wanita yang bukan mahramnya. Inilah salah satu bagian terpenting dikenalkan kedudukan orang-orang yang haram dinikahi dalam pendidikan seks anak. Dengan demikian dapat diketahui dengan tegas bahwa Islam mengharamkan incest, yaitu pernikahan yang dilakukan anatar saudara kandung atau mahramnya. Siapa saja mahram tersebut. ${ }^{19}$

7. Mendidik anak agar selalu menjaga pandangan mata.

Telah menjadi fitrah bagi setiap manusia untuk tertarik dengan lawan jenisnya. Namun, jika fitrah tersebut dibiarkan

${ }^{16}$ Qs. al-Ahzzab (33): 13.

${ }^{17}$ Ilmawati, "Pendidikn Seks...", 26.

${ }^{18}$ Ibid.

${ }^{19}$ Ibid. 27. 
bebas lepas tanpa kendali, justru hanya akan merusak kehidupan manusia itu sendiri. Begitu pula dengan mata yang dibiarkan melihat gambar-gambar atau film yang mengandung unsur pornografi. Karena itu, jauhkan anakanak dari gambar, film, atau bacaan yang mengandung unsur pornografi dan pornoaksi. ${ }^{20}$

8. Mendidik anak agar tidak melakukan ikbtilât.

Ikbtilat adalah bercampur baurnya laki-laki dan perempuan bukan mahram tanpa adanya keperluan yang dibolehkan oleh syari'at Islam. Perbuatan semacam ini pada masa sekarang sudah dianggap biasa. Mereka bebas mengumbar pandangan, saling berdekatan dan bersentuhan seolah tidak ada lagi batas yang ditentukan syari'at guna mengatur interaksi diantara mereka. Ikbtilat dilarang karena interaksi semacam ini bisa menjadi mengantarkan pada perbuatan zina yang diharamkan Islam. Karena itu, jangan biasakan anak diajak ke tempattempat yang di dalamnya terjadi percampuran laki-laki dan perempuan secara bebas. ${ }^{21}$

9. Mendidik anak agar tidak melakukan khalwat.

Dinamakan khalwat jika seorang laki-laki dan wanita bukan mahram-nya berada di suatu tempat, hanya berdua saja. Biasanya mereka memilih tempat yang tersembunyi, yang tidak bisa dilihat oleh orang lain. Sebagaimana ikhtilât, khalwat pun merupakan perantara bagi terjadinya perbuatan zina. Anak-anak sejak kecil harus diajari untuk menghindari perbuatan semacam ini. Jika bermain, bermainlah dengan sesama jenis. Jika dengan yang berlainan jenis, harus diingatkan untuk tidak berkhalwat. ${ }^{22}$

10. Mendidik etika berhias.

Berhias, jika tidak diatur secara Islami, akan menjerumuskan seseorang pada perbuatan dosa. Berhias berarti usaha untuk

\section{${ }^{20} \mathrm{Ibid}$. \\ ${ }^{21}$ Ibid. \\ ${ }^{22}$ Ibid.}


memperindah atau mempercantik diri agar bisa berpenampilan menawan. Tujuan pendidikan seks dalam kaitannya dengan etika berhias adalah agar berhias tidak untuk perbuatan maksiat. ${ }^{23}$

11. I I tilâm dan haid

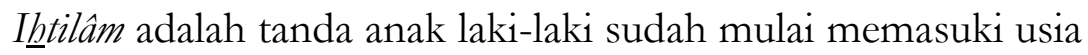
baligh. Adapun haid dialami oleh anak perempuan. Mengenalkan anak tentang ibtilâm dan haid tidak hanya sekedar untuk memahami anak dari pendekatan fisiologis dan psikologis semata. Jika terjadi ibtilâm dan haid, Islam telah mengatur beberapa ketentuan yang berkaitan dengan masalah tersebut, antara lain kewajiban untuk melakukan mandi. Yang paling penting, harus ditekankan bahwa kini mereka telah menjadi muslim dan muslimah dewasa yang wajib terikat pada semua ketentuan syari'at. Artinya, mereka harus diarahkan menjadi manusia yang bertanggung jawab atas hidupnya sendiri sebagai hamba Allah yang taat. Itulah beberapa hal yang harus diajarkan kepada anak berkaitan dengan pendidikan seks. ${ }^{24}$

\section{Pornografi dan Pornoaksi sebagai Deviasi Seksual}

Pengertian dari deviasi seksual yaitu gangguan dari arah dan tujuan aktivitas seksual terhadap obyek tidak lazim agar mendapatkan kepuasan. Deviasi seksual sangat banyak macamnya terdiri dari homoseksual/lesbianisme yaitu perilaku seksual dilakukan pada sesama jenis; fethisme perilaku terhadap sebuah benda misal sepatu, pakaian dalam, kaos kaki, atau rambut; pedofilia perilaku dilakukan pada anak yang belum matang secara seksual; ransvesitisme dengan cara memakai pakaian dan berperan sebagai lawan jenis; zoofilia perilaku seksual lewat binatang untuk mencapai kepuasan; proumerisme

${ }^{23}$ Ibid, 28.

${ }^{24}$ Ibid. 
menggosok-gosokan tubuh pada lawan jenis. Ada dua segi abnormalitas dari seksual yaitu segi fungsi dan kejiwaan. Perilaku seksual masyarakat yang sangat banyak dijumpai dimasyarakat namun tidak disadari yaitu exhibisionisme dan voyeurisme. ${ }^{25}$ Voyeurisme/skopofilia perilaku di mana seseorang mengamati aktivitas seksual atau ketelanjangan selain pasangan pernikahan dengan maksud mencari kepuasan seksual. Sebagian besar masyarakat mungkin tidak menyadari gejala-gejala awal dari gangguan jiwa ini.

Gangguan kejiwaan seksual ini terkait dengan masalah pornoversal, ${ }^{26}$ yaitu perilaku seksual yang menyimpang secara menyeluruh, terutama pornografi dan pornoaksi yang marak sekarang diperbincangkan. Banyak yang tidak menyadari bahwa ternyata seks bebas merupakan sebuah penyakit kejiwaan. orang yang mengalami gangguan jiwa bermacam-macam, misalnya pada exhibisionisme tingkat ringan mungkin seseorang hanya memperlihatkan sebagian tubuhnya misal lengan dalam, dan paha. Dan dia dikatakan menderita gangguan jiwa berat jika organ vitalnya sudah dipertontonkan. Begitu pula dengan voyeurisme biasanya gejala-gejala awal dari penyakit jiwa ini terlihat dimana seseorang sudah menganggap wajar pornografi, melihat secara sembunyi-sembunyi seseorang lagi mandi ataupun bertukar pakaian langsung ataupun lewat media apapun. Penyakit ini makin parah jika dia tidak dapat mengendalikan diri

${ }^{25}$ Cara seperti ini, tanpa disadari telah diolelir oleh pemerintah maupun masyarakat Indonesia secara umum, yaitu dengan cara mengadakan event kecantikan, ratu kecantikan, miss universe, binaragawan/binaragawati, striptease, dan sejenisnya. Mereka itu menampilkan lekuk tubuh sehingga hampir 90\% auratnya, lebih menyedihkan lagi yang bersangkutan merasa senang dan puas. Atau seseorang yang memperlihatkan anggota tubuh yang merangsang terutama alat kelamin selain partner/pasangan pernikahan dengan maksud mencapai kegairahan seksual, kepuasan baik materi maupun non materi.

26Ivan Albar, "Bebas dari Pornografi adalah Bebas dari Gangguan Jiwa", Blog, 16 Maret 2006. 
melihat secara langsung aktivitas seksual maupun pornografi dari orang lain secara berulang kali.

Jika penyimpangan kejiwaan seksual demikian tidak dicegah, maka dalam jangka panjang dapat menjadi penyakit masyarakat, sebagaimana yang terjadi di masyarakat yang mengagungagungkan kebebasan, termasuk kebebasan seksual. Kinsey dalam sebuah penelitiannya, ${ }^{27}$ pernah menggemparkan masyarakat Amerika dengan diterbitkannya buku yan berjudul Sexual Behavior Of The Human Female, hasil penelitiannya disimpulkan bahwa 50\% dari wanita Amerika sejak bangku sekolah (setingkat SMP) telah berhubungan seksual tanpa menikah. Sebanyak 64\% wanita yang sudah bersuami dan bekerja di kantor-kantor sudah melakukan hubungan seksual sebelum nikah.

Seorang ahli seksologi terkemuka di Amerika, Arthur T. Jesild, mengatakan bahwa lebih dari setengah kelompok wanita normal yang belum kawin yang berusia 15-30 tahun dan yang sudah kawin yang berusia 22-32 tahun, menyatakan pengalaman mereka yang pertama tentang hubungan seksual yang telah terjadi sebelum mencapai pubertas. ${ }^{28}$ Ini menunjukkan bahwa telah terjadi kecepatan kematangan bagi anak-anak gadis Amerika dari segi kehidupan seksualitas. Dan masih banyak lagi data-data yang menunjukkan hal yang sama di negara-negara lain. Akar penyebab semua ini adalah ideologi kebebasan yang diusung dan merembet pada permisivisme di media (cetak dan elektronik), moral dan etika dalam menyalurkan naluri seksual.

\section{Kebebasan, Agama dan Keamanan Sosial}

Pornografi dan pornoaksi selalu menjadi momok masyarakat untuk dikaitkan dengan HAM, kebebasan, dan keamanan sosial.

${ }^{27}$ M. Yusuf, "Angka-angka dari Dr. Kinsey”, Angkatan Baru, 101 (Juli, 1968), 3.

${ }^{28}$ Arthur T. Jesild, Psikologi Anak, ter. Conny Semiawan dan Muchtar Buchori (Bandung: Terate, 1992), 275. 
Dalam terminologi Islam, kebebasan (al-burriyah) merupakan antitesis perbudakan. Oleh karena itu, kebebasan adalah yang memungkinkan manusia untuk memilih melakukan atau tidak melakukan bidang apapun, dan dengan media ekspresi apapun.

Batasan Islam terhadap kebebasan manusia ini mengikat kebebasan berinisiatif "sebagai kewajiban manusia" dengan "kewajiban-kewajiban syari'at Islam" dan melihat hak-hak manusia dalam hubungannya dengan hak-hak Allah. Yaitu dengan membatasi kebebasan inisiatif dan tindakan manusia di dunia dari melakukan tindakan-tindakan yang dapat menghasilkkan azab, ketakutan dalam keamanan sosial, dan keburukan di akhirat. pornografi dan pornoaksi dalam tataran kebebasan dan HAM sejatinya tetap berpijak pada kewajiban melaksanakan norma dan nilai-nilai religuisitas sehingga ketenangan dan keamanan sosial dapat terwujud.

Karena itu, meski agama mampu menghasilkan individu yang bertakwa, tetap saja perlu adanya kontrol masyarakat dan negara dalam mengelola kebebasan demi tercapainya tujuan keamanan sosial tersebut. ${ }^{29}$ Rincinya adalah sebagai berikut:

1. Peran individu

Suatu aturan Allah swt. akan bisa diterapkan oleh setiap individu yang bertakwa yang memiliki keimanan yang kokoh kepada sang pembuat hukum, yaitu Allah swt. Ketakwaan dan keimanan yang kokoh didapat dengan cara pembinaan yang intensif dalam membentuk kepribadian Islam (syakhshiyah islamiyyah) melalui penanaman ilmu-ilmu keislaman (tsaqôfah islamiyyah) yang memadai, dengan menjadikan akidah dan syari'at Islam sebagai pijakannya.

2. Peran masyarakat

Para ulama, tokoh-tokoh masyarakat dan komponenkomponen lainnya yang ada di masyarakat hendaklah

${ }^{29}$ Najmah Saiidah, "Mengatasi Pornografi dan Pornoaksi", al-Wa'ie, 30 April 2006, 15. 
bersama-sama dan bersinergi mengontrol setiap kerusakan yang terjadi di tengah-tengah umat. Saling mengingatkan merupakan senjata yang paling ampuh, termasuk mengingatkan agar para penguasa tidak lalai dalam menjalankan amanahnya. Mereka pun berkewajiban untuk mencerdaskan umatnya melalui pembinaan umat secara keseluruhan dan berlangsung terus-menerus tanpa henti agar umat juga berani mengingatkan pemimpinnya. Karenanya, Islam sangat memperhatikan 'kesehatan masyarakat'. Masyarakat yang sehat hanya terwujud dengan terlaksananya amar makruf nabi munkar di tengah-tengah masyarakat oleh seluruh komponen masyarakat, baik maupun penguasa.

3. Peran negara

Tanpa menyandarkan pada argumen teologis tertentu, pornografi menjadi problem kemanusiaan yang semestinya menjadi agenda bersama seluruh komunitas agama. Pornografi juga sangat mungkin mendorong desakralisasi seks yang pada gilirannya menyebabkan setumpuk penyakit sosial, seperti AIDS dan penyakit menular seksual lainnya, perkosaan, kehamilan remaja, aborsi, perselingkuhan, perceraian, hidup bersama tanpa ikatan pernikahan, pelacuran, dan homoseksual/lesbian. Rekomendasi Sidang Tahunan MPR melalui TAP MPR No. VI Tahun 2002 kepada Presiden agar mengambil langkah mencegah pornografi dan pornoaksi harus menjadi stimulasi lahirnya regulasi yang mengatur masalah pornografi dan pornoaksi.

Dalam pandangan Islam, negara tidak hanya bertanggungjawab memelihara akidah Islam rakyatnya, tapi juga melaksanakan hukum-hukum Allah secara sempurna di tengahtengah kehidupan. Aparat negara tidak perlu bersikap reaktif; dengan menunggu masyarakat marah dan kemudian merusak sarana-sarana maksiat (termasuk arena pornoaksi atau tempattempat penjualan pornografi). Aparat negaralah yang seharusnya proaktif melakukan pencegahan sesuai dengan syari'at Islam. 
Burrhus F. Skinner, seorang psikolog pada Universitas Harvard dengan teori "operant conditioning" yaitu sebuah konsep pengawasan terhadap lingkungannya. Membangun suatu sistem untuk menciptakan suatu dunia dengan "manusia yang pada dasarnya baik". Eksopsikiatri merupakan ilmu yang mempelajari masalah psikiatrik akibat interaksi manusia dan lingkungan ataupun hubungannya antara interaksi dengan perilaku yang menyimpang. Eksopsikiatrik antara lain berusaha mencegah atau mengubah perilaku yang menyimpang itu melalui pengaruh lingkungan. Built enviroment memudahkan timbulnya perilaku yang baik dan menyukarkan timbulnya perilaku menyimpang.

Pengaturan negara itu termasuk pada media yang mempunyai peran besar dalam menyuburkan perilaku pornografi dan pornoaksi dalam masyarakat. Karena, sejak reformasi tahun 1998, media di Indonesia demikian bebas menyampaikan informasi kepada masyarakat, apalagi setelah dicabutnya SIUPP yang membuat media di Indonesia tidak khawatir lagi akan ditutup jika menampilkan berita yang tidak sesuai dengan kebijakan pemerintah. Yang terjadi kemudian adalah kebebasan versi media yang bersangkutan, termasuk ukuran pantas tidaknya sebuah photo atau tayangan visual untuk konsumsi umum yang kadangkala untuk sebagian orang dianggap tidak sesuai dengan norma-norma ketimuran yang dianut oleh (sebagian besar) masyarakat Indonesia. Foto-foto seronok, tari-tarian yang ditarikan oleh penari dengan pakaian yang minim dan terbuka, sinetron-sinetron remaja yang menampilkan wajah-wajah indo dengan model busana yang ketat dan minim yang memperlihatkan lekuk tubuh yang seksi, seolah-olah menjadi hal yang biasa dikonsumsi masyarakat.

Penampilan-penampilan di atas yang oleh sebagian kalangan masyarakat dianggap sebagai pornografi dan pornoaksi malahan oleh anak-anak muda dianggap keren dan up to date, apalagi yang menampilakan artis-artis idola remaja yang biasanya menjadi teladan mereka dalam model pakaian, gaya rambut dan gaya 
hidup. ${ }^{30}$ Dengan semakin sering tampilnya tokoh-tokoh idola remaja berperan dalam peran-peran "panas" atau berpakaian minim dan terbuka di berbagai majalah remaja atau acara-acara TV, berarti juga media massa membantu menyebarkan pornografi dan pornoaksi, walaupun media massa berdalih bahwa semuanya itu sedang trend atau menjadi keinginan pembaca atau pemirsa. Melalui media yang selama ini tergambar, sebenarnya dapat memberikan keterangan pada banyak orang bahwa demikianlah perilaku seksual yang terjadi di masyarakat tersebut, dan karena media juga dapat dijadikan salah satu parameter tingkah laku yang berlaku dimasyarakat.

\section{Catatan Akhir}

Berdasarkan paparan di atas, perdebatan dan perbedaan pandangan mengenai pornografi dan pornoaksi bermula dari pemahaman yang berbeda mengenai sesuatu yang layak diperlihatkan dan atau sesuatu yang layak dilihat sesuai norma ketimuran, kelayakan nilai seni atau perbuatan melalui pandangan HAM dan norma agama yang memberi batasan dengan tegas dan jelas.

Pendekatan adat dan budaya lokal membandingkan naluri atau selera pribadi jelas tidak relevan dan tidak akan mampu untuk menghukumi nilai sesuatu, terlebih itu sebuah penyakit kejiwaan berupa melihat dan memperlihatkan bagian tubuh yang selayaknya tidak diperlihatkan. Karena adat, budaya lokal, dan naluri merupakan sesuatu yang bersifat relatif, tidak akan sama pandangan dan pemahaman masyarakat lokal bila dihadapkan masalah kejiwaan tersebut. Dan lebih tepatnya untuk menghukuminya yaitu dengan nilai-nilai religiusitas dan normatif, maka nilai itu bersifat absolut.

${ }^{30}$ Lucinda dan Suryo Adi Pramono, "Globalisasi, Media Massa dan Edukasi Kaum (Sebuah Tinjauan Sosiologis)", Dinamika Masyarakat, No. 3, (November, 2005), 776. 
Dengan memahami akar permasalahan, fakta sebab dan akibat maka diharapkan masyarakat luas mampu bersikap tegas dan membentengi diri dari perilaku penyimpangan seksual dan dampak negatif dari penyimpangan perilaku tersebut.

\section{Daftar Pustaka}

Arthur T. Jesild, Psikologi Anak, ter Muchtar Buchori dan Conny Semiawan (Bandung: Terate, 1992).

Ivan Albar, "Bebas dari Pornografi Adalah Bebas dari Gangguan Jiwa", Blog, 16 Maret 2006.

Karam al-Bastânî, al-Munjid Fi al-Lughah wa-al-'Alam (Beirût: Dâr al-Masyriq, 1987)

Lucinda dan Suryo Adi Pramono, "Globalisasi, Media Massa dan Edukasi Kaum (Sebuah Tinjauan Sosiologis)," Dinamika Masyarakat, 3, (November, 2005).

Muhammad M. Ismail, Al-Fiker al-Islâmî, ter. A. Haidar (Bangil: al-Izzah, 2004).

M. Yusuf, "Angka-angka dari Dr. Kinsey", Angkatan Baru, 101 (Juli, 1968).

Muhammad Imarah, al-Islam Wa al-Amn al-Ijtimâ’i (Kairo: Dâr alSyurûq, 1998)

Neng Djubaedah, Pornografi Dan Pornoaksi Ditinju Dari Segi Hukum Islam (Jakarta: Kencana, 2003).

Najmah Saidah, "Mengatasi Pornografi dan Pornoaksi", al-Wa'ie, 30 April 2006.

Yusuf al-Qardlawi, al-Sunna: Mashdaran li al-Ma'rifah wa alHadlarah, ter. Faizah Firdaus (Surabaya: Dunia Ilmu, 1997).

Purwadarminta, Kamus Besar Bahasa Indonesia (Jakarta: Balai Pustaka, 1989)

al-Qur'an dan Terjemahannya (Madinah: Mujamma' al-Malik Fahd li al-Thibâ'at al-Mushaf al-Syarif 1418 H).

Sayyid Sabiq, Fiqh al-Sunnah (Kairo: Dâr al-Fath lil 'Ilam Arabi, 1996). 
Wahbah al-Zuhaylî, al-Fiqh al-Islâmî wa Adillatubu, Jilid I (Damaskus: Dâr al-Fikr, 1997)

Yatimin, Etika Seksual Dan Penyimpangannya Dalam Islam: Tinjauan Psikologi Pendidikan Dari Sudut Pandang Islam (Pekanbaru: Amzah).

Zulia Ilmawati, "Pendidikan Seks Untuk Anak", Al-Wa'ie, 30 April 2006. 